\author{
Available online at JECE (Journal of Early Childhood Education) \\ Website: http://journal.uinjkt.ac.id/index.php/jece \\ Permalink/DOI: http://dx.doi.org/10.15408/jece.v3i1.17205 \\ JECE, 3 (1), Juni 2021, 65-74
}

\title{
SOCIAL BEHAVIOR OF EARLY CHILDREN IN THE NUSUKAN RAILWAY ENVIRONMENT, SURAKARTA
}

\author{
Afi Zumrotul Fikria, Sri Hartini, Feri Faila Sufa \\ Universitas Slamet Riyadi, Indonesia \\ Corresponding e-mail: afizumrotulf98@gmail.com
}

\begin{abstract}
Children's social development is how early childhood interacts with peers, adults, and the broader community to adapt. Parents and the environments are figures or models closest to children and become role models for children. This study aimed to determine children's social behavior and the role of the environment on the social behavior of children aged 5-6 years in the Nusukan Surakarta railway environment. This type of research uses descriptive qualitative methods - sampling using a purposive sampling technique. The data analysis technique used the Milles and Huberman model with three stages: data reduction, presentation, and conclusion. The results show that children's social behavior in the Nusukan railway area tends to be active, but some behaviors still need guidance so that children have good social behavior. It is inseparable from family environmental factors, both parents, siblings, peers, or other adults through their environment. Child development is strongly influenced by treatment or parental guidance for children in recognizing various aspects of social life or norms of social life. Social behavior is closely related to children's behavior in adjusting to the rules of society in the surrounding environment. Children obtain social behavior through maturity and learning opportunities from various stimuli provided by their environment.
\end{abstract}

Keywords: Social Behavior, Early Childhood, railway environment

\begin{abstract}
Abstrak
Perkembangan sosial anak adalah bagaimana anak usia dini berinteraksi dengan teman sebaya, orang dewasa dan masyarakat luas agar dapat menyesuaikan diri. Orang tua dan lingkungan merupakan sosok atau model yang paling dekat dengan anak dan menjadi panutan bagi anak. Tujuan dari penelitian ini adalah untuk mengetahui perilaku sosial anak dan Peran lingkungan terhadap perilaku sosial anak usia 5-6 tahun di lingkungan rel kereta api Nusukan Surakarta. Jenis Penelitian ini menggunakan metode kualitatif deskripstif. Pengambilan sample menggunakan teknik purposive sampling. Teknik analisis data menggunakan model Milles dan Huberman dengan tiga tahapan, yaitu reduksi data dilanjutkan dengan penyajian data dan diakhiri dengan penarikan kesimpulan. Hasil menunjukan bahwa perilaku sosial anak di daerah rel kereta api Nusukan cenderung aktif, namun ada perilaku yang masih sangat membutuhkan bimbingan, supaya anak memiliki perilaku sosial yang baik. Hal ini tidak terlepas dari faktor lingkungan keluarga, melalui lingkungannya baik orang tua, saudara, teman sebaya ataupun orang dewasa lainnya. Perkembangan anak sangat dipengaruhi oleh proses perlakuan atau bimbingan orang tua terhadap anak dalam mengenal berbagai aspek kehidupan sosial, atau norma-norma kehidupan bermasyarakat. Perilaku sosial berhubungan erat pada perilaku anak dalam menyesuaikan diri dengan aturan-aturan masyarakat di lingkungan sekitar. Perilaku sosial diperoleh anak melalui kematangan dan kesempatan belajar dari berbagai stimulus yang diberikan lingkungannya.
\end{abstract}

Kata kunci : Perilaku Sosial, Anak Usia Dini, lingkungan rel kereta api 


\section{Introduction}

Children's social development is early childhood's ability to interact with peers, adults, and the broader community to adapt appropriately according to what is expected by the nation and state. In the early days of life, children learn from those closest to them. That is why, apart from guiding and teaching children how to get along correctly, parents also need to be good models for their children. In emotional development, the modeling process of the microenvironment can be formed when the child gets a stimulus in the form of emotional experiences from the people around him (Mayar, 2013).

The environment is an essential part of early childhood because the formation of children's character cannot be separated from their social environment. The environment is essential in social development because the environment is everything that is around children, both internal and external stimuli, both physiologically, psychologically, and socio-culturally (Zahroh \& Na'imah, 2020). When viewed from the perspective of social workers, good interactions between parents and children can create a conducive relationship that significantly influences the development of their children. This interaction can be built by doing activities together (Asriyah, Taftazani, \& S., 2016).

Parents and the environments are figures or models closest to children and become role models for children. In this case, the child does not only imitate what he sees, but the child also imitates what the child hears (Aisyah, Jaenudin, \& Koryati, 2017). The child will immediately imitate whatever he catches from his family and environment as material for his new knowledge, regardless of what he gets is good or bad. Whatever behavior children get from their parents and their environment is stored in mind as the concept of the child's behavior. In addition, the culture or habits of the surrounding community also affect (Shasliani, 2020).

Social development is the achievement of maturity in social relations. It can also be interpreted as a learning process to adapt to group norms, morals, and traditions, merge into a single unit and communicate and cooperate. Children's social development is strongly influenced by the treatment or guidance of parents in the family and teachers, principals, and other education personnel in schools in introducing various aspects of social life, or norms of social life or encouraging and providing examples to children on how to apply norms in everyday life. Children's social behavior is characterized by an interest in friends' activities and increases a solid desire to be accepted as a member of a group, and is not satisfied when not with friends. So it can be concluded that social development is the achievement of maturity in social relations. It can also be interpreted as a learning process to conform to norms, morals, and traditions. Merge themselves into a unit that communicates and cooperates (Musyarofah, 2017). The factors that influence the social development 
of AUD include family environmental factors, factors from outside the home, factors influencing children's social experiences (Hijriati, 2019).

Achievement of social development of children aged 5-6 years: the ability to communicate, cooperate, share, participate, and adapt, sympathy, empathy, solve problems, and discipline according to applicable rules and norms. Social skills in children aged 5-6 years, which are well developed, are characterized when social relations with friends can be seen from the child's attitude in fostering interpersonal and intrapersonal relationships (Susanti, Sumardi, \& Nugraha, 2020).

Children's people daily influence children's growth and development, especially in their socio-emotional, intellectual, moral, and spiritual aspects. A conducive environment can encourage children's physical and mental development well, while a non-conducive environment can cause children to be below their abilities (Suyadi, 2010).

So that children can play and learn well, it is necessary to strive to have good friends and good social development and supervision from parents. The people that children meet every day have a significant influence on children's growth and development. It is necessary to have an excellent environment to positively influence children so they can play and learn as well as possible.

According to the behavioristic approach, humans can have positive or negative tendencies because their personality is shaped by the environment in which they are located. Humans as environmental products can be positive or negative depending on where they live. The language used can be adopted and born through the closest association with family and neighbors around their environment. The imitation process is also carried out in the home environment and outside the home when they are with their friends (Razi, Siregar, \& Zulkarnain, 2018). The point is that the surrounding environment is very influential on children's social behavior.

Social behavior is closely related to children's behavior in adjusting to the rules of society in the surrounding environment. Children obtain social behavior through maturity and learning opportunities from various stimuli provided by their environment. A good and healthy social environment can help children develop positive self-concepts and support optimal socialization (Tri A, 2016). Children's social problems are a term to describe a group of children whose rights, conditions, and cultural pressures and structures have not been fulfilled, or their rights have not been fulfilled, and their rights are often violated (Bagong Suyanto, 2010).

From the explanation of children's social problems above, the author wants to know how early childhood social behavior occurs in the railway environment, how children interact with the closest environment, namely family and the outside 
environment, namely the surrounding community, and to find out the actual reality of how children play with peers.

Residential settlements located on the outskirts of the RT 02/ RW 15 railway line, Nusukan Sub-district become an environment for children's play. The sound of trains and dust flying because the trains are almost crowded every day, making children play and interact in an environment that is not conducive. Lack of supervision and Parental guidance has an impact on children's social behavior. Following the problems above, the purpose of this study is to examine in-depth social behavior and the role of the environment from the home environment, peers, and the play environment to the social behavior of children aged 5-6 years in the Nusukan Surakarta railway environment.

\section{Method}

This type of research uses descriptive qualitative methods, namely writing to collect data directly from the field and then interpret and conclude from the existing data. Qualitative research has a particular tradition in the social sciences, which fundamentally depends on observing humans in their area and events (Moleong, 2018).

This study uses a purposive sampling technique, namely determining informants based on specific criteria or considerations; the criteria are children who live in the railway environment who are about 5-6 years old and parents who live in the suburbs of the railway tracks-data collection techniques through direct observation (observation) and interviews. Sources of data in this study are 1)children as the subject of the research. The child becomes the most critical part because what the child does (plays, interacts with parents or the surrounding community), what the child speaks (the language used by the child in everyday life), what is written and felt by the child is all observed and explained again through the research procedures carried out by the child. Generate descriptive data; 2) - parent or guardian of the child. Children's parents or guardians are part of children's lives who interact and watch children grow and develop every day. Researchers observed children's behavior when children were at home and interacted with their families to meet the data source. The researcher also asked several questions to validate the findings with the children's previous daily behavior and document the findings as part of the researcher's evidence of the research. 3). Communities around the neighborhood where the child lives. The community is also part of the data source because it is the closest environment for children after their families. Observations and interviews were carried out directly in residential areas located on the outskirts of the RT 02/RW 15 railway line, Nusukan Village. For public health and safety reasons from the covid-19 pandemic, this study only examined one subject with 
observations from a predetermined distance. It carried out a home visit to complement the data based on observations, interviews, and documentation of the observed children's social behavior.

Researchers observed children playing and interacting with the community where they lived to see children's behavior towards the surrounding community. The researcher also asked several questions related to the social behavior of children in the environment. Data from local community testimonies about the behavior of the children being studied are used to strengthen the findings previously obtained from the sources of the parents or guardians and the children being studied. Some of the references used by researchers are books, journals, articles, field notes, and photos.

The validity of the data was carried out by method triangulation and source triangulation, namely comparing and cross-checking with the persistence method. The data analysis technique used the Milles and Huberman model with three stages: data reduction, presentation, and conclusion. Data reduction such as summarizing, choosing the main things, and focusing on the essential things. Data presentation, Data presentation, is presented in the form of narrative text. The data is presented by grouping according to the respective sub-chapters. Moreover, drawing conclusions or verification, the next step is concluding. After describing various data obtained, the researcher makes a conclusion which is the result of a study.

\section{Results and Discussion}

Based on the results of the study, information was obtained about the condition of settlements. Residential settlements in the Nusukan railway environment, which are located on Rt $02 / \mathrm{Rw} 15$. This settlement is a type of settlement pattern in the form of linear stretching along the railway tracks. This settlement is located about $\pm 5 \mathrm{~m}$ from the train tracks. According to government regulations, it is not that the demarcation line and railway tracks for buildings are > $20 \mathrm{~m}$.

The research subjects in this study were children with the initials R. Based on interviews and observations of researchers with resource persons, namely children, parents, and the surrounding community. It was found that $\mathrm{R}$ lived with his father, mother, brother, and sister-in-law, and two of R's other sisters. $\mathrm{R}$ is the last child with an age gap of more than a dozen years with his brothers.

R's parents and brothers who are busy working place $\mathrm{R}$ in the condition of parents who ignore their children's condition; this can be seen in the absence of 
special prohibitions on children so that children have complete freedom in playing what they want. It is also influenced by parenting from parents. In the R family, there are no restrictions or punishments given by parents, so that children often play around the railway tracks or sit near the train tracks. Family environmental factors make children feel free to do all they want when they are at home without fear of punishment and binding rules when playing in the environment around the house; this parenting style makes parents give freedom without control, do not mind the child playing with anyone and playing until any time. Habits in everyday life in the form of actions are a form of behavior. This indifference to children leads to permissive parenting. Children are given the freedom to do or decide something without any direction from parents; this kind of parenting affects children's social behavior. As in the research conducted by Makagingge et al., it is said that permissive parenting harms children's social behavior, namely the higher the permissive parenting applied by the child's parents, the lower the child's social behavior. Permissive parenting will cause children to behave as they wish, be selfish, and not give in when playing with their friends, so they do not readily accept them. (Makagingge, Karmila, \& Chandra, 2019).

The social behavior of imitating in playing with his friends has been seen when $\mathrm{R}$ imitates his friends playing bicycles, balls, kites, hide and seek, or just sitting near the train tracks. Besides imitating an exact pattern of behavior is the competition that is often seen by $\mathrm{R}$ when playing a bicycle. R's cooperative behavior emerged when playing ball together by dividing tasks and dribbling the ball to scoring goals. It is in line with Utami's research that says that the peer environment influences $57 \%$ of children's social behavior (Utami, 2018).

R's social behavior is inseparable from family environmental factors, through the environment either parents, siblings, peers, or other adults. Child development is strongly influenced by the treatment process or parental guidance for children in recognizing various aspects of social life or life forms. Community and encourage and provide examples to their children how to apply these norms in everyday life. This parental guidance process is commonly called socialization.

Based on interviews and observations, researchers found that the railway environment was not conducive or dangerous for children to play because it was near the railway tracks. Dangers in the railway environment were accidents like being hit by a train. In addition, the railway environment is also not the right environment to live in. Besides being dangerous, the railway environment is also dangerous for children to play in. It is certainly not under the principle of the playing 
environment, namely the children's play environment must make children feel safe, make children feel comfortable, and develop children's confidence. An environment arranged according to the child's condition can build children's confidence to do it. An environment full of challenges but safe for children to do encourages children to find solutions to overcome every challenge that exists. This fosters creativity and an unyielding attitude (Pendidikan, Kemdikbud, \& Gedung, 2018).

From the results of the presentation above, it can be seen that the social behavior of children in daily interactions shows indications of behavior that tends to be "active," but there are social behaviors of children who still need guidance to become better, such as discipline following applicable rules and norms. Many children on the railway tracks use playgrounds that are not per the rules. Their playing schedule and activities are also irregular, thus affecting their discipline attitude. It is indicated by the patterns of communication and actions taken by children in everyday life. Several factors that influence include the surrounding environment and parents. If the family environment, peers, and the surrounding environment are good, then social behavior will also be good. It is by the role of the family, especially parents, who can spend time with their children and can also be facilitated or provide a place for children to play with the supervision of their parents, namely through the playground and others. (Hulukati, 2015). It is further strengthened because it is the family sphere which is the first sphere of influence to the children (Ummah \& Fitri, 2020).

Apart from busy parents, children should be educated and cared for in socializing so that children's development in behavior and moral attitudes in a social environment is also good, but the fact is that children are free to do anything and get along with anyone. Parents should not leave their responsibilities even though they are busy with busy routines that focus on trading and mediocre daily activities. Parents still have to control children's activities (Dasopang, 2018).

Peers also have a role in social behavior. It is through Peers that children and adolescents learn how to interact in symmetrical and reciprocal relationships. Children learn to formulate and express opinions, respect peer points of view, negotiate solutions to disputes cooperatively, and change standards of behavior accepted by all through peers (Utami, 2018). It shows that behavior can affect a person; there is a correlation between their behavior and the environment. In all routines, it cannot be separated from interaction; the interaction that occurs is the application of social behavior (Mansyur Romadhon Putra, 2016). 


\section{Conclusion}

Children are great imitators and want to try new things that they do not understand and know about. So as parents need to give understanding and direction to children which behavior is good to imitate and which behavior is not good to imitate. Because basically, children need to know and distinguish good and bad behavior from an early age to prepare them when they grow up so that children do not make mistakes. Social behavior is closely related to children's behavior in adjusting to the rules of society in the surrounding environment. Children obtain social behavior through maturity and learning opportunities from various stimuli provided by their environment. According to the child's development, the right stimulus or stimulus will help the child enter the next stage of development well. Parenting given and applied by parents will significantly affect children's growth and development and success in further development, ranging from personality, mental, moral, social, and spiritual.

Parents should be able to set a rule for children playing on the edge of the train tracks. Parents are expected to pay more attention to the child's growth and development process, to recognize disturbances or obstacles in the child's interaction process with the environment as early as possible. Parents are expected to apply democratic parenting to their children because too much behavior that gives children freedom can be a bad thing in the future. Furthermore, community leaders in the rt 02 rw 15 railway environment in Nusukan Surakarta guide good behavior in speech and action. It is necessary to make written rules regarding the prohibition of playing on the edge of the railway tracks and the dangers and consequences of playing on the edge of the railway tracks.

\section{References}

Aisyah, Jaenudin, R., \& Koryati, D. (2017). Analisis Faktor Penyebab Rendahnya Hasil Belajar Peserta Didik pada Mata Pelajaran Ekonomi di SMA Negeri 15 Palembang. Jurnal Profit, 4(1), 1-11.

Asriyah, P. W., Taftazani, B. M., \& S., M. B. (2016). Peranan Orang Tua Terhadap Perilaku Anak Sebagai Pemirsa Televisi Dirumah. Prosiding Penelitian Dan Pengabdian Kepada Masyarakat, 3(2). https:/ / doi.org/10.24198/jppm.v3i2.13693

Bagong Suyanto. (2010). Masalah Sosial. Jakarta: Prenada Media Group.

Dasopang, M. A. (2018). Pengaruh Lingkungan dan Kebiasaan Orangtua Terhadap Perilaku dan Sikap Moral Anak. Journal of Civic Education, 1(2), 98-107. 
Hijriati. (2019). Faktor dan Kondisi yang Mempengaruhi Perkembangan Sosial Emosional Anak Usia Dini. Jurnal Pendidikan Anak Usia Dini, V(2), 94-102.

Hulukati, W. (2015). Peran Lingkungan Keluarga terhadap Perkembangan Anak. Musawa, 7(2), 265-282.

Makagingge, M., Karmila, M., \& Chandra, A. (2019). Pengaruh Pola asuh Orang Tua terhadap Perilaku Sosial Anak (Studi Kasus Pada Anak Usia 3-4 Tahun di KBI Al Madina Sampangan Tahun Ajaran 2017-2018). Jurnal Pendidikan Anak Usia Dini, 3(2), 115-122.

Mansyur Romadhon Putra. (2016). Perilaku Sosial Anak Pekerja Batu Kali Social Behaviour of the Children of River Stone Labour. Jurnal Ilmiah Visi PPTK PAUDNI, 11(1).

Mayar, F. (2013). Perkembangan Sosial Anak Usia Dini Sebagai Bibit Untuk Masa Depan Bangsa. Al-Ta Lim Journal, 20(3), 459-464. https:/ / doi.org/10.15548/jt.v20i3.43

Moleong, L. J. (2018). Metode Penelitian Kualitatif. Bandung: PT. Remaja Rosdakarya.

Musyarofah, M. (2017). Pengembangan Aspek Sosial Anak Usia Dini Di Taman Kanak-Kanak Aba Iv Mangli Jember Tahun 2016. INJECT (Interdisciplinary Journal of Communication), 2(1), 99. https:// doi.org/10.18326/inject.v2i1.99-122

Pendidikan, K., Kemdikbud, K. P., \& Gedung, E. (2018). Pengelolaan kelas.

Razi, A. D., Siregar, M., \& Zulkarnain, Z. (2018). Children Imitation on Daily Languages Family Counseling Perspective. ENLIGHTEN (Jurnal Bimbingan Dan Konseling Islam), 1(2), 139-149. https:/ / doi.org/10.32505/ enlighten.v1i2.774

Shasliani. (2020). Upaya Penanganan Kesulitan Belajar Siswa Pada Mata Pelajaran IPS di SMP Negeri 24 Makassar Tahun 2019. Heritage, 1(1), 23-42. https://doi.org/10.35719/hrtg.v1i1.2

Susanti, S., Sumardi, S., \& Nugraha, A. (2020). Keterampilan Sosial Anak Usia 5-6 Tahun Di Kelompok B Tk Aisyiyah 2. Jurnal Paud Agapedia, 3(1), 89-100. https:/ / doi.org/10.17509/jpa.v3i1.26671

Suyadi, dkk. (2010). Psikolog Belajar Pendidikan Anak Usia Dini. Yogyakarta: Pedagogia.

Tri A, F. L. (2016). Perilaku Sosial Anak Usia Dini di Lingkungan Lokalisasi Guyangan (Studi Kasus pada Anak Usia 5-6 Tahun). Jurnal PG-PAUD Trunojoyo, $3(1), 1-75$.

Ummah, S. A., \& Fitri, N. A. N. (2020). Pengaruh Lingkungan Keluarga Terhadap 
Perkembangan Sosial Emosional Anak Usia Dini. SELING (Jurnal Program Studi PGRA), 6(1), 84-88.

Utami, D. T. (2018). Pengaruh Lingkungan Teman Sebaya Terhadap Perilaku Sosial Anak Usia 5-6 Tahun. Generasi Emas, 1(1), 39. https:/ / doi.org/10.25299/ge.2018.vol1(1).2258

Zahroh, S., \& Na'imah, N. (2020). Peran Lingkungan Sosial terhadap Pembentukan Karakter Anak Usia Dini di Jogja Green School. Jurnal PG-PAUD Trunojoyo: Jurnal Pendidikan Dan Pembelajaran Anak Usia Dini, 7(1), 1-9. https:/ / doi.org/10.21107/pgpaudtrunojoyo.v7i1.6293 